\title{
POSISI STRATIGRAFI DAN TEKNOLOGI ALAT SERPIH SANGIRAN
}

Oleh: Harry Widianto

Persoalan alat paleolitik dan manusia purba, masih merupakan persoalan menarik dalam hakekat sejarah perkembangan manusia. Keduanya tidak dapat dipisahkan kaitannya selama Kala Plestosen, yaitu suatu periode kehidupan antara dua juta hingga 10.000 tahun silam. Oleh sifatnya yang tahan terhadap kekuatan destruktif alam, alat-alat batu yang sederhana tersebut telah dianggap bukti tentang eksistensi manusia saat itu. Bukti-bukti kehidupan tersebut ditemukan kembali dalam endapan Plestosen yang terbentuk, antara lain endapan-endapan teras sungai purba. Asal-usul manusia menjadi begitu kontroversiil selama berabad-abad, dan meliputi masa yang sangat gelap. Penemuan sisa-sisa Pithecanthropus erectus oleh Eugene Dubois di Desa Trinil pada tahun 1890 dan 1891, merupakan penemuan yang sempat menggemparkan dunia pengetahuan, dan hingga pertengahan abad 20 telah menjadi suatu legenda.

Terusik oleh anggapan bahwa daerah tropis tidak banyak mengalami perubahan iklim dan memungkinkan manusia purba hidup, maka sampailah Dubois seorang dokter militer Belanda, di Indonesia. Dipilihnya gua-gua Sumatra Barat sebagai lokasi penelitian pertama dalam usaha mendapatkan sisa-sisa manusia purba. Di sini ia tidak menemukannya, dan ia kemudian memindahkan perhatiannya ke Jawa setelah mendengar penemuan manusia Wajak di Jawa Timur. Akhirnya ia menemukan sisa-sisa Pithecanthropus erectus tersebut. Temuan ini meliputi fragmen atap tengkorak, dua buah gigi geraham, dan sebuah tulang paha kiri. Keletakannya terserak satu sama lain, tetapi Dubois menganggapnya sebagai milik satu individu (Hoop. 1938:13). Posisi stratigrafinya terletak dalam endapan volkanik yang berupa tufa pasiran, yang dimuntahkan dari G. Lawu dan G. Wilis pada kala Plestosen Tengah (Bartstra, 1982 a:243). Oleh karenanya. 
seluruh temuan yang berasal dari spesimen tersebut dianggap berasal dari Kala Plestosen Tengah. sekaligus menunjukkan umur $\mathrm{Pi}$ thecanthropus erectus. Suatu persoalan mengenai asal-usul manusia mulai terkejar.

Setelah Dubois kembali ke Belanda, penelitian pada lokasi yang sama dilanjutkan oleh ekspedisi Selenka, yang melakukan eksplorasi besar-besaran di Trinil untuk mendapatkan spesimen sejenis lainnya. Ekspedisi ini berlangsung tahun 1906-1908, dan telah memindahkan bukit-bukit tanah di Trinil. Penggalian Dubois yang tidak kecil itu menjadi tenggelam karenanya. Ratusan fragmen fosil ditemukan oleh Selenka, tetapi seluruhnya berasal dari binatang vertebrata yang termasuk dalam Fauna Trinil, antara lain: stegodon trigonochepallus dan Hippopotamus antiqunus, tanpa satupun fragmen tulang yang berasal dari manusia. Untuk sementara, penelitian mengenai manusia purba beserta alatnya terhenti sejak berakhirnya ekspedisi Selenka.

Tahun 1934, kembali daerah Jawa dipakai sebagai ajang penelitian manusia purba dan alatnya. G.H.R. von Koenigswald, seorang paleontolog yang bekerja untuk Dinas Geologi Bandung, melakukan penggalian pada sebuah bukit di sebelah timur laut Sangiran, Jawa Tengah. Lereng-lereng bukit ini merupakan lapisan tufa pasiran yang kaya dengan fosil, dan puncaknya merupakan endapan gravel kasar. Alat-alat batu yang berupa alat serpih telah ditemukan pada lapisan gravel tersebut, beberapa di antaranya menunjukkan ciri-ciri teknologis buatan manusia, antara lain adanya kerucut pukul (bulbus) dan perimping bekas pemakaian di pinggiran alat. Hasil penelitian ini merupakan pemacu penelitian lainnya di daerah Sangiran, terutama setelah ditemukan fragmen rahang bawah dan atas dari spesimen Meganthropus paleojavanicus A oleh Koenigswald pada tahun 1941, Meganthropus paleojavanicus B oleh P. Mark pada tahun 1942, dan beberapa spesimen Pithecanthopus sp. yang hingga saat ini sudah dikumpulkan sekitar 30 individu. Posisi stratigrafi Pithecanthropus sp. bernomor Sangiran 1 sampai dengan Sangiran 20 telah diteliti oleh Otto Sudarmadji berdasarkan litostratigrafi, biostratigrafi dan kronostratigrafi (Sudarmadji, 1976:94). Akhirnya, daerah Sangiran telah tampil sebagai salah satu situs terkemuka mengenai manusia purba beserta alatnya. 
Sangiran merupakan sebuah kubah yang terbentuk oleh adanya proses deformasi, baik secara lateral maupun vertikal. Proses erosi pada puncak kubah telah menyebabkan terjadinya reveerse, kenampakan terbalik, sehingga daerah tersebut menjadi daerah depressi. Bagian tengah kubah Sangiran ditoreh oleh Kali Cemoro dan cabangcabangnya sebagai sungai enteseden, sehingga menyebabkan formasi batuannya tersingkap dan menunjukkan bentuk melingkar. Stratigrafi daerah Sangiran dari tua ke muda terbagi menjadi: Formasi Kalibeng (Pliosen Atas), Formasi Pucangan (Plestosen Bawah), Formasi Kabuh (Plestosen Tengah), Formasi Notopuro (Plestosen Atas), dan endapan sub-resen Kali Cemoro (Sartono, 1978:20).

Pada Kala Pliosen, daerah ini menjadi laut dangkal. Kemudian terjadi kegiatan gunung berapi, mungkin dari G. Merapi dan G. Lawu. Akibatnya, pada daerah ini terbentuk Formasi Kalibeng dengan litologi terdiri atas tufa, napal, dan kalkarenit yang mengandung glaukonit. Adanya regresi lebih lanjut pada daerah ini menyebabkan Sangiran menjadi daratan. Pada permulaan Kala Plestosen Bawah kegiatan volkanis semakin meningkat, sehingga terjadi aliran lahar dingin dan membentuk breksi volkanik. Aliran lahar yang deras tersebut mengangkut banyak sekali binatang dari Fauna Jetis, yang kemudian diendapkan pada laguna yang terbentuk. Manusia fosil $\mathrm{Me}$ ganthropus sp. mungkin muncul pada saat kegiatan vulkanis melemah, sehingga fosil-fosilnya ditemukan pada formasi yang terbentuk kemudian (Sudarmadji, 1976:25).

Pada Kala Plestosen Tengah, Sangiran menjadi daratan lagi, disusul dengan kegiatan vulkanis yang semakin menghebat sehingga menimbulkan endapan tufa yang berlapis-lapis dan menjadi bagian terbesar Formasi Kabuh. Proses pengangkatan tanah pada daerah ini terjadi pada Kala Plestosen Atas dan awal Kala Holosen, sehingga lapisan-lapisan batuannya terlipat dan membentuk kubah. Adanya pelapukan dan erosi pada puncak kubah, serta pengendapan material Kali Cemoro, menyebabkan kenampakan Sangiran menjadi seperti sekarang ini. Manusia yang hidup pada saat itu, misalnya: Meganthropus paleojavanicus, Pithecanthropus erectus dan Pithecanthropus soloensis, banyak yang terkabur dalam formasi tersebut. 
Dalam penggalian yang telah dilakukan Koenigswald di desa Ngebung tahun 1934, endapan gravel ditunjuk sebagai lapisan budaya pengandung alat-alat serpih Sangiran. Sisa fosil vertebrata Fauna Trinil dari jenis Axis lydekkeri dan Stegodon ditemukan pada lapisan yang sama dengan alat-alat tersebut, sehingga kaitan antara keduanya menunjukkan umur Plestosen Tengah, sehingga kaitan antara keduanya menunjukkan umur Plestosen Tengah, dan diperkirakan bahwa alat-alat tersebut merupakan hasil budaya Pithecanthropus erectus (Koenigswald and Ghosh, 1973:1). Berbagai kritik mengenai hasil pertanggalan tersebut mulai bermunculan, antara lain oleh de Terra, Movius dan Tielhard de Chardin. Bahkan Bartstra menolak tegas istilah lapisan Trinil bagi stratigrafi Sangiran. Sisa-sisa vertebrata yang terdapat pada bagian paling atas dari lapisan Trinil di Sangiran bukan merupakan hasil pengendapan primer, melainkan merupakan hasil pengendapan sekunder (Bemmelen, 1949:566). Lapisan tersebut tidak mengandung fosul Fauna Trinil dalam posisi autokhton, dan inilah sebabnya tidak ada satu alasanpun untuk mengatakan bahwa alat serbih-bilah tersebut berasosiasi dengan hominid Plestosen Tengah (Bartstra, 1978:68). Penentuan umur alat-alat paleolitik sebaiknya ditinjau melalui posisinya dalam litostratigrafi, dengan meninggalkan data paleontologis.

Dalam penelitian mengenai manusia purba, Helmut de Terra, Hallam L. Movius, dan Tielhard de Chardin telah sampai di Sangiran, yang tergabung dalam The Joint American - Southeast Asiatic Expedition for Early Man. Penelitian stratigrafis mengenai alat-alat Sangiran yang dilakukan ketiganya menunjukkan bahwa alat-alat serpih tersebut berada dalam endapan krakal dari Formasi Notopuro, yang terletak tidak selaras di atas lapisan tufa dari Formasi Kabuh (Plestosen Tengah). Tidak terdapat satu artefakpun yang ditemukan di bawah gravel Formasi Notopuro, dan industri serpih bilah yang berada pada lapisan atas telah menunjukkan hasil teknologi yang dianggap terlalu maju bagi Pithecanthropus erectus (de Terra and Movius, 1943:456). Alat-alat ini sama sekali tidak menyerupai alat-alat $P i$ thecanthropus erectus dari Plestosen Tengah, misalnya yang ditemukan di gua Chou-Kou-Tien (Cina). Sebaliknya, alat-alat tersebut menunjukkan kesamaan dengan hasil industri aretefak Plestosen Atas, yang antara lain ditemukan di Ngandong. Bagi pendukung alat-alat Sangiran, lebih logis seandainya dihubungkan dengan Pithecantropus soloensis dibandingkan dengan Pithecantrhropus erectus. 
Kesimpulan di atas digarisbawahi oleh Bartstra melalui beberapa kerja lapangannya di Sangiran. Menurut Bartstra, lapisan gravel pengandung alat-alat tersebut jauh lebih muda umurnya dibandingkan dengan lapisan tufa di bawahnya (Bartstra, 1982a:249), sehingga artefak tersebut tidak akan lebih tua dari 130.000 tahun, yaitu usia tertua bagi Formasi Notopuro dari Kala Plestosen Atas (Bartstra, 1982b: 319). Dengan demikian, Plestosen Atas merupakan usia yang diterima bagi alat-alat Sangiran, dan Pithecanthropus soloensis dianggap sebagai pendukung industri alat-alat Sangiran. Selain di Ngebung, alatalat Sangiran ditemukan pula di desa Tanjung, Pucung, Ngrawan, dan Bapang.

\section{III}

Alat-alat batu Sangiran menunjukkan dominasi alat serpih dan bilah, sehingga menyebabkan munculnya istilah industri serpih-bilah bagi himpunan alat di situs ini. Bahan utamanya adalah kalsedon kuning tembus, coklat, dan jasper merah dengan bentuk-bentuk alat untuk keperluan pengiris, serut, gurdi, dan penusuk, yang bahanbahannya banyak ditemukan dalam endapan konglomerat Formasi Notopuro. Ukuran alat berkisar antara $2-4 \mathrm{~cm}$, sehingga menunjukkan ukuran alat yang jauh lebih kecil dibandingkan dengan alat Paleolitik lainnya, misalnya alat-alat dari Pacitan. Bahkan di situs Sangiran ini jarang ditemukan unsur alat-alat batu masif, meskipun beberapa batu inti terlihat pada koleksi Koenigswald. Dengan demikian terdapat perbedaan menyolok dengan situs paleolitik lainnya di Indonesia yang umumnya merupakan bagian perkembangan kompleks kapak perimbas-penetak, dan perbedaan ini telah dianggap jebagai ciri spesifik dari himpunan alat-alat batu Sangiran.

Penelitian mengenai teknologi dan tipologi alat-alat Sangiran secara mendalam telah dilakukan oleh Koenigswald dengan pembagian tipe alat ke dalam tipe yang terperinci, lebih dari 30 tipe. Tipe-tipe tersebut secara umum dapat dikembalikan ke dalam tipe alat serpih (flake), bilah (blade), dan bilah-serpih (blade like flake). Koenigswald menganggap bahwa pembagian tipologi alat-alat Sangiran yang diciptakan pada tahun 1973 tersebut belum mencapai kesempurnaan, dan bahkan ia menunjuk tipologi alat non-masif oleh Movius tahun 1968 merupakan tipologi yang terbaik, seperti dikatakan: 
"The very recent method of attribute analysis of major classes of tools appear to be significant for precise classification. The same methodology has found to be fruitful in specific region, where the typological sequence is clear. In this connection, the best example of such work is that of Movius et.al, 1968" (Koenigswald and Ghosh, 1973:9).

Setelah Movius berhasil dengan tipologi yang diciptakan untuk paleolotik Birma dan Pacitan, maka kembali diciptakan tipologi untuk alat-alat non-masif, terutama bagi temuan Plestosen Akhir. Dalam metode kerja tipologi tersebut, Movius telah menciptakan tipologi detil bagi alat-alat serpih (flake), bilah (blade), serut (scraper), dan burin. Tidak saja disajikan hasil tipologinya, melainkan diberikan pula atribut teknologisnya, pengukuran sudut tajaman, ratio pemakaian, proses pembuatan, dan sebagainya (Movius et. al, 1968:1 - 36). Meskipun mengakui tipologi Movius adalah yang terbaik, tetapi sangat aneh bahwa dalam perincian tipologi Koenigswald bagi alat-alat Sangiran, hasilnya jauh menyimpang dari ketentuan Movius. Mungkin sekali bahwa tipologi Koenigswald tersebut lebih dipengaruhi oleh keyakinannya tentang usia Plestosen Tengah bagi industri alatalat Sangiran.

Teknologi umum yang terdapat pada himpunan alat batu Sangiran adalah teknik clacton. Teknik ini dicirikan oleh bentuk-bentuk alat serpih tebal, disertai dengan lebarnya sudut antara permukaan bulbar dan dataran pukulnya. Teknik ini terlihat pula sangat menonjol pada kelompok alat-alat serpih Sangiran (Bartstra, 1976:76). Bahkan tipe pahat genggam (hand adze) dan proto kapak genggam (proto hand axe) dari Pacitan selau dibuat dari serpih tebal (Movius, 1943: 459).

Alat-alat serpih Sangiran dibuat melalui dua tahapan pengerjaan. Tahap pertama adalah melepaskan serpih dari batu intinya, dan dilanjutkan dengan tahap kedua, yaitu pengerjaan pada serpihan yang terlepas, untuk mendapatkan bentuk-bentuk yang sesuai dengan suatu fungsi khusus (Koenigswald and Ghosh, 1973:8). Dengan demikian, proses pembuatan alat melalui penyerpihan kedua (secondary retouched) merupakan ciri utama pada alat-alat serpih Sangiran. Proses penyerpihan kedua ini kadang-kadang akan mengaburkan bagian dorsal dan ventralnya. 
Sebagian besar alat-alat serpih Sangiran menunjukkan bentuk bentuk pendek, lebar, dan tebal. Letak kerucut pukulnya bervariasi. antara lain terdapat pada bagian ujung atau bahkan pada sudut alat. Pembuatan alat serpih melalui pemukulan tidak langsung (indirectpercussion) merupakan gejala menonjol, disertai dengan kontrol cermat, terbukti dengan bentuk-bentuk dan ukuran alat yang teratur. Akan halnya alat-alat bilah, sebagian besar menunjukkan sisi tajaman pada satu sisi. Sisi lainnya dibiarkan tumpul, sehingga menghasilkan penampang irisan dengan bentuk mendekati segitiga. Sebagian alat ini menunjukkan perimping bekas pakai, tetapi tidak jarang ditemukan pula alat bilah tanpa perimping, sehingga menunjukkan kesan belum dipakai.

Selain kedua alat tersebut di atas, terdapat pula jenis alat lainnya yaitu alat bilah-serpih (blade like flake). Jenis ini menunjukkan kombinasi bentuk alat serpih dan bilah. Keadaan di atas seakan-akan memberikan indikasi bahwa perkembangan teknologi alat serpih ke alat bilah merupakan satu rangkaian proses. Jenis bilahserpih ini dihasilkan dalam tahap peralihan yang terletak di antara tahap pembuatan alat serpih dan alat bilah.

Ciri teknologis utama yang terlihat pada alat-alat Sangiran, yaitu pengerjaan primer melalui pemukulan langsung yang dilanjutkan dengan pengerjaan sekunder yang menghasilkan alat serpih dengan kisaran ukuran antara $2-4 \mathrm{~cm}$, telah memberikan gambaran tentang ketrampilan yang dimiliki oleh manusia pendukungnya. Pola pembuatan alat serpih yang matang telah dikuasai sepenuhnya oleh sang pembuat. Alat-alat ini setingkat lebih maju dibandingkan dengan alat sejenis dari himpunan alat Pacitanan, meskipun teknik dasarnya adalah sama, yaitu teknik clacton. Alat serpih Pacitan menunjukkan bentuk dan ukuran yang tidak teratur. Pengerjaan kedua masih belum jelas terlihat seperti halnya pada alat-alat Sangiran. Lebih majunya alat-alat Sangiran dapat diterima secara logis, karena posisi alat-alat Pacitan setingkat lebih tua dibandingkan de ngan alat-alat Sangiran. Alat-alat Pacitan ditafsirkan berasal dari Kala Plestosen Tengah bagian akhir (yang dihubungkan dengan Pithecanthropus erectus) hingga Kala Plestosen Atas bagian awal (yang didominasi oleh Pithecanthropus soloensis). Proses evolusi biologis yang terjadi pada kedua jenis manusia tersebut telah menghasilkan pula proses evolusi kulturalnya. Evolusi, sejauh tidak terjadi penyim- 
pangan, akan menghasilkan bentuk-bentuk sederhana ke bentuk progressif. Alat batu dari tingkatan Plestosen merupakan refleksi adaptasi bio-kultural dari manusia Plestosen itu sendiri (Harry Widianto, 1981: 34).

Suatu permasalah yang kemudian muncul pada himpunan alatalat Sangiran adalah: dominannya alat-alat serpih-bilah dan sulit sekali ditemukan alat-alat masif. Keadaan ini akan sangat berbeda dengan alat-alat Pacitan, yang menghasilkan perbandingan sejajar antara alat masif dan non-masif. Jelas bahwa alat-alat kedua situs tersebut merupakan hasil teknologi Kala Plestosen, yang dicirikan dengan pola perburuan binatang dan pengumpulan makanan sebagai mata pencaharian hidup. Berdasarkan konsep tersebut, tampaknya faktor perburuan merupakan faktor penentu yang teiah mengarahkan perubahan-perubahan bentuk, ukuran, maupun fungsi. Dominasi binatang pada Kala Plestosen Tengah adalah binatang besar, seperti Stogodon trigonochepallus, Cervus lydekkeri, maupun Hippopotamus antiqunus (Clark, 1972:89, cf. Hutterer, 1984:131, Soejono, 1984: 59). Dengan demikian, secara otomatis akan dihasilkan alat-alat masif berukuran besar yang lebih cocok untuk suatu pekerjaan berat, seperti yang terlihat pada himpunan alat-alat Pacitan. Pithecanthropus erectus yang ditemukan oleh Dubois berasosiasi langsung dengan sisa-sisa binatang besar (Hoop, 1938:13).

Akan halnya dengan alat-alat Sangiran, belum ada gejala yang jelas mengenai asosiasi langsung dengan sisa-sisa binatang dalam satu konteks. Mungkin telah ada kecenderungan untuk memilih binatang kecil dalam perburuan mereka, karena ukuran alatnya yang demikian kecil. Ataupunpengumpulan makanan lebih ditonjolkan dari pada perburuan binatang. Keadaan yang lebih nyata tampak pada tingkatan mesolitik dari Kala Post-Plestosen, terutama páda lingkup budaya Toala. Alat-alat Toala yang berupa mikrolit, mata panah bersayap atau bergerigi, alat serpih dan bilah bergerigi, lancipan tebal sesisi, dan lancipan Muduk, menunjukkan aktifitas perburuan binatang kecil (Soejono, 1984:156). Dugaan seperti ini mungkin dapat diterapkan terhadap alat-alat Sangiran, mengingat ukuran dan bentuk alat yang mendukung ke arah dugaan tersebut. Lingkup yang lebih luas menunjukkan keadaan sebagai berikut: terdapat perbedaan alat antara Kala Plestosen Tengah bagian akhir hingga Plestosen Atas bagian awal (budaya Pacitan) - Plestosen Atas bagian akhir (budaya 
Sangiran) - Post Plestosen/Awal Holosen (budaya Toala). Secara fisik, perbedaan alat itu dapat dijabarkan sebagai: alat masif/nonmasif (Pacitan) - alat serpih/bilah (Sangiran) - mikrolit/serpihbilah/lancipan (Toala). Posisi alat-alat Sangiran tampaknya berada pada peralihan antara teknologi Pacitan dan teknologi Toala, yang secara periodisasi terletak dalam Kala Plestosen bagian paling akhir. Mungkin dalam hal ini, alat-alat Sangiran dapat dianggap sebaai "proto-mesolitik", yang kemudian berkembang secara pesat pada masa sesudahnya. Persoalan mengenai fungsional alat-alat tersebut masih disajikan secara spekulatip, karena mencakup suatu periode masa yang telah lama berlalu. 


\section{Daftar Pustaka}

Bartstra. Gert Jan. 1978. "Recent Palaeolithic Research in Java (Kali Glagah.

Pacitan. Gombong. Sangiran): The First Six Months of a New Project". Modern Quaternary Research in Southeast. Vol. 4. Rotterdam : A.A Balkema. Halaman 63 - 70 .

Bartstra. Gert Jan. 1982a. "Op Zoek naar de Werktuigen van de Javamens". Spiegel Historiael: Manblaad voor Geschiedenis en Archeologie. Haarlem: tanpa penerbit. Halaman 242 - 249.

Bartstra. Gert Jan. 1982b. "Homo erectus erectus: The Search for His Artifacts". Current Anthropology. Vo. 23. No. 3. Tanpa kota penerbit: Halaman $318-320$.

Bemmelen. R.W van. 1949. "General Geology of Indonesia and Adjacent Archipelagoes", the Geology of Indonesia. Vol. IA. The Hague: Martinus Nijhoff.

Clark. W.E Le Gros. 1972. The Fossils Evidence for Human Evolution. Chicago: University of Chicago Press.

de Terra. Hellmut and Hallam L. Movius Jr. 1943. "Research on Early Man in Burma". Transaction of American Philosophical Society. Vol. XXXII. Part Ill. Philadelphia: The American Philosophical Society. Halaman 267 - 463.

Hoop. AN.J Th. a Th. van der. 1938. "De Praehistorie". Geschiedenis van Nederlandsch Indie I. Amsterdam: N.V Uitgeversmaatchappij. Halaman: 7 - 111.

Hutterer. Karl L. 1984. "Reinterpreting the Southeast Asian Palaeolithic" dalam Prehistoric Indonesia. A Reader. Leiden : Foris Publications Holland. Halaman: $121-162$.

Koenigswald. G.H.R von and Asok K. Ghosh. 1973. "Stone Implements from The Trinil Beds of Sangiran. Central Java". Proc. Koninlijk van Wetenschappen. Series B. No. 1. Amsterdam: penerbit tidak diketahui. Halaman: 1 - 34 .

Movius. Hallam L. Jr. et. al. 1968. "The Analysis of Certain Major Classes of Upper Palaeolithic Tools". American School of Prehistoric Research Peabody Museum. Bull. No. 26. Cambridge: Harvard University. 
Sudarmadji. Otto. 1976. Tinjauan Mengenai Pithecanthropus sp. dan Posisi Stratigrafi lapisan-lapisan Pengandungnya di Sangiran, Jawa Tengah.

Yogyakarta : Fakultas Teknik (Bagian Teknik Geologi) UGM. Tidak diterbitkan.

Sartono, S. 1978. "The Site of Homo erectus Mandible F". Modern Quaternary Research in Southeast Asia Vol. 4. Rotterdam : A.A Balkema. Halaman $19-24$.

Soejono, R.P (editor). 1984. Sejarah Nasional Indonesia I. Jakarta. Departemen Pendidikan dan Kebudayaan.

Widianto, $H$. (1981). TEKNOLOGI PLESTOSEN SUATU HASIL ADAPTASI BIO-KULTURAL. Berkala Arkeologi. 2(1). 32-35. https://doi.org/10.30883/ jba.v2i1.288 


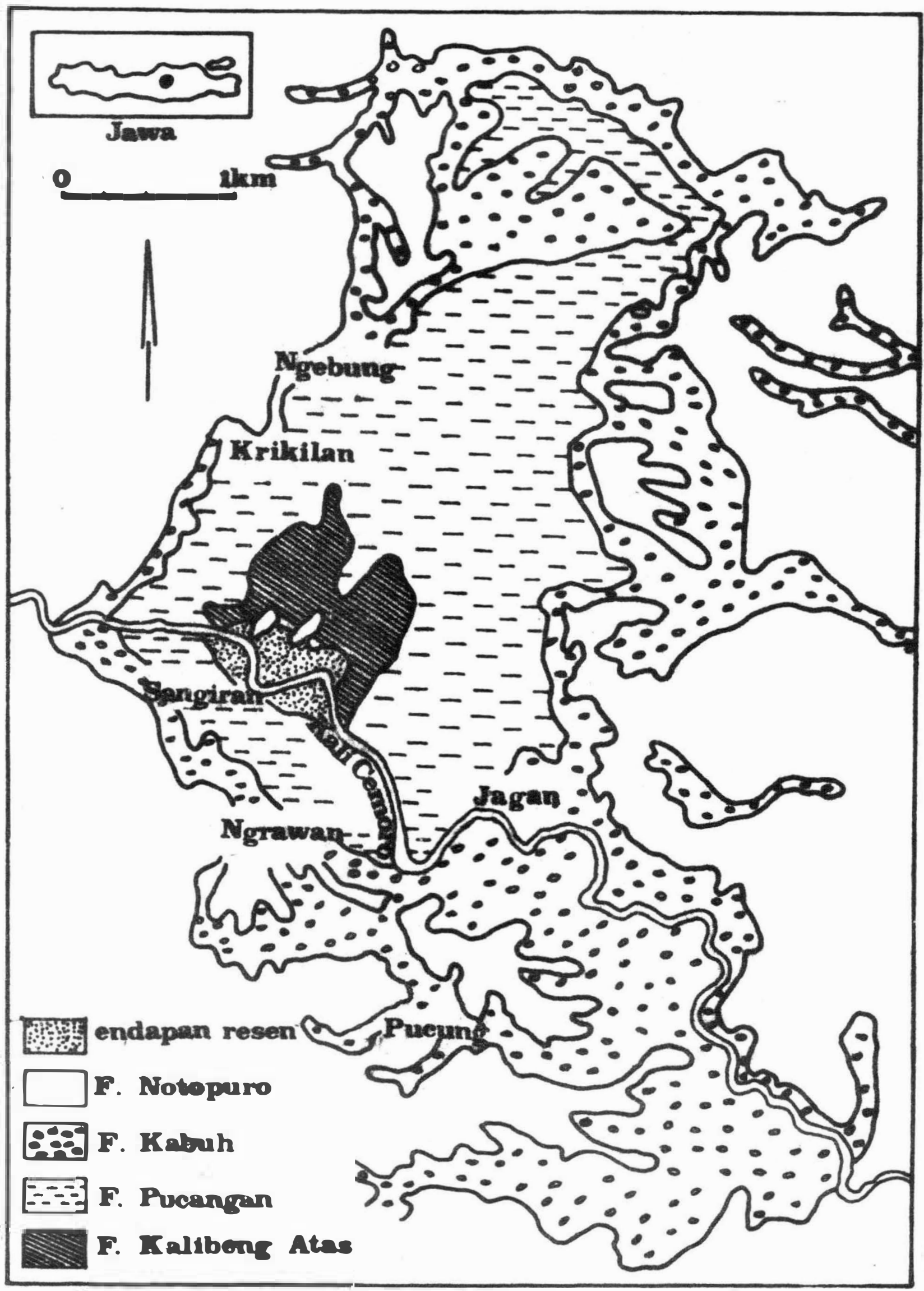

(Menurut D. Wayne Orchiston, 1978) 


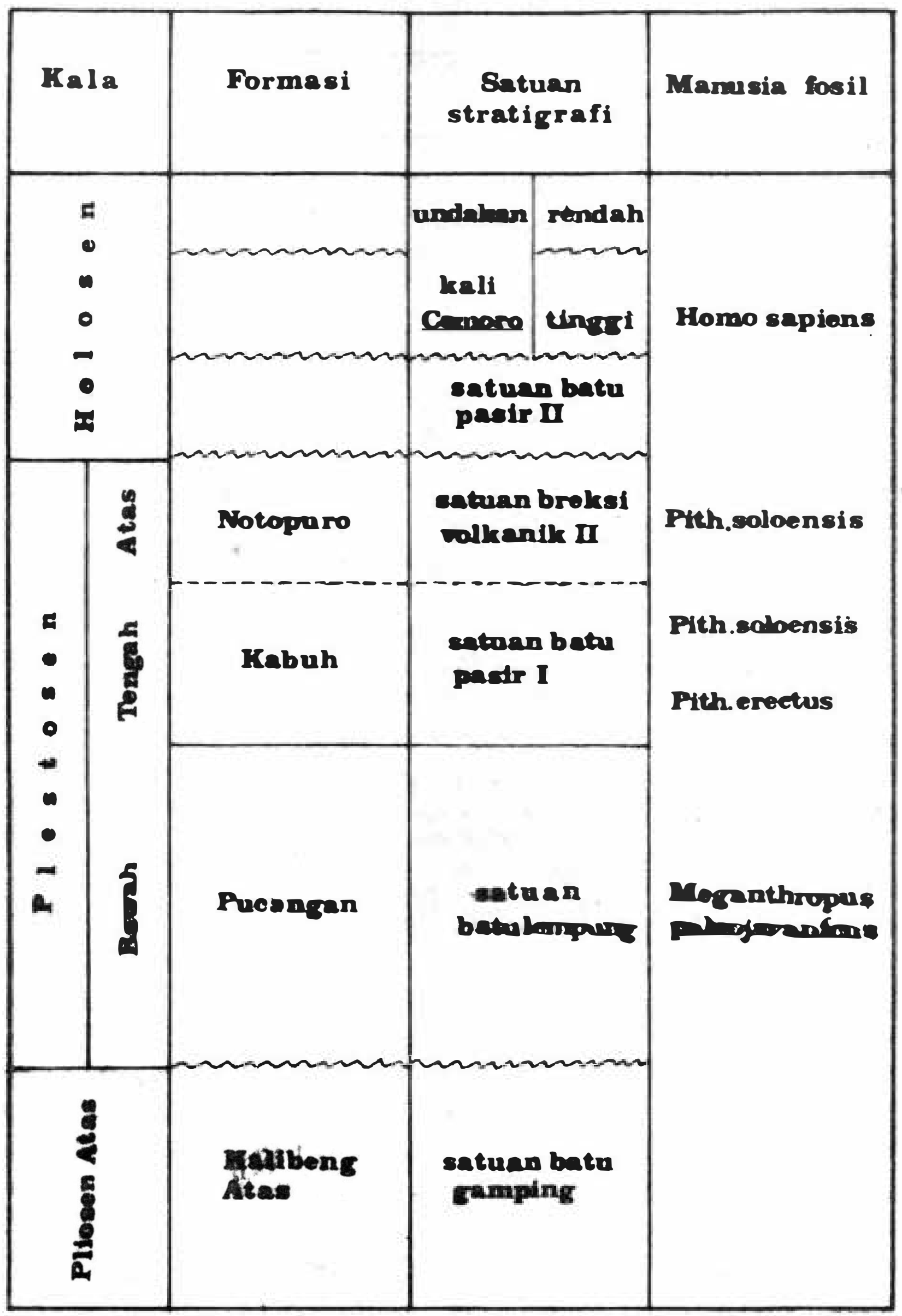

sumber : Sejarah Nasional Indanesia I . dengan perubahan sopertunya.

m ketidak selarasan 
KORILASI BUDAYA SANGIRAN DENGAN BUDAYA LAINNYA

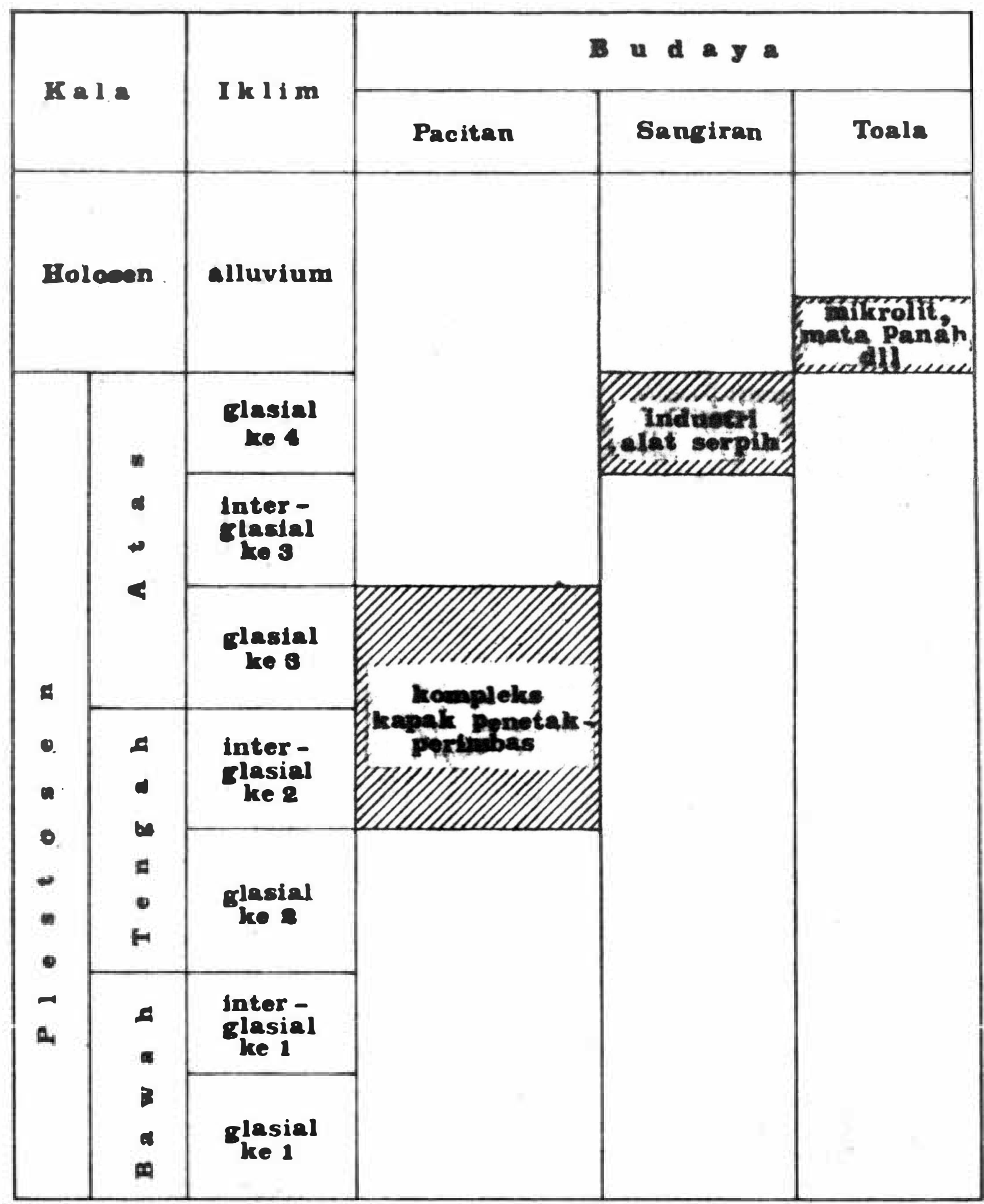

